\title{
Elimination of Phytoplasmas in Rubus Mother Plants by Tissue Culture Coupled with Heat Therapy
}

\author{
Holger Linck, ${ }^{1, \dagger}$ Christa Lankes, ${ }^{2}$ Erika Krüger, ${ }^{3}$ and Annette Reineke ${ }^{1}$ \\ ${ }^{1}$ Department of Crop Protection, Hochschule Geisenheim University, 65366 Geisenheim, Germany; ${ }^{2}$ Institute of Crop Science \\ and Resource Conservation - Horticultural Science, University of Bonn, 53121 Bonn, Germany; and ${ }^{3}$ Department of Pomology, \\ Hochschule Geisenheim University, 65366 Geisenheim, Germany
}

\begin{abstract}
Phytoplasmas are plant-pathogenic bacteria that cause a disease in Rubus species which is referred to as Rubus stunt. As phytoplasmas can be spread by vegetative propagation and latency periods of Rubus stunt can be up to one year, the use of pathogen-free Rubus propagation material in plant nurseries is important in order to stop the spread of this disease. Even though heat therapy has been commonly applied against viruses in many plants, its potential for phytoplasma eradication has been much less explored. Here, the efficacy of heat therapy with subsequent tissue culture to eliminate phytoplasmas from infected raspberry and

blackberry plants is evaluated. Heat therapy was performed on 25 phytoplasma-infected raspberry and 33 infected blackberry plants, out of which 100 raspberry and 65 blackberry plants were regenerated via subsequent tissue culture. All plants were negative for the presence of phytoplasma DNA by qPCR at the end of cultivation periods of 481 to 565 days for the treated raspberry plants and 231 to 337 days for the treated blackberry plants. These results show the suitability of heat therapy combined with tissue culture as a routine tool to ensure the presence of phytoplasma-free Rubus mother plants in nurseries.
\end{abstract}

For the production of healthy planting material of any vegetatively propagated crop plant, the elimination of disease agents in propagation material (mother plants and nuclear stock material, respectively) is necessary. This is especially critical for phytoplasma and virus infections, as they can spread inside the mother plant without showing any symptoms (latency period) (Mannini 2007; Martin et al. 2013). Heat therapy, which was used as early as 1869 when Scottish gardeners immersed bulbs in hot water before planting, is the oldest method used to remove viruses, viroids, and phytoplasmas from vegetatively propagated plants (Zandbergen 1964). Generally, when performing heat therapy nowadays, plants are incubated in a temperature cabinet at $30-40^{\circ} \mathrm{C}$ for a period of 6 to 12 weeks with subsequent in vitro plant tissue cultures using meristem tips (Varveri et al. 2015). Doing so, more than 100 different pathogens may be eliminated from one plant simultaneously (Nienhaus 1985). Therefore, heat treatment is a valuable and already well-tried tool to eliminate pathogens from plants (Varveri et al. 2015) and is, for example, integrated in the certification scheme for fruit trees in Germany (Lenz and Lankes 2006).

Phytoplasmas are cell wall-less plant-pathogenic bacteria which colonize the phloem of their host plants and can be transferred by insect vectors, grafting, or vegetative propagation (Bertaccini 2007). In Rubus species, they cause a disease called Rubus stunt, which consists of symptoms like stunting, witches'-broom, small leaves, short internodes, enlarged sepals, phyllody, flower proliferation, and fruit malformations (Mäurer and Seemüller 1995). Heat therapy was reported to cure phytoplasma diseases for the first time in 1936 for peach yellows (Kunkel 1936), followed by aster yellows (Kunkel 1941), potato witches'-broom (Kunkel 1943), and cranberry false

${ }^{\dagger}$ Corresponding author: H. Linck; holger.linck@hs-gm.de

Funding: This research was supported by Bundesministerium für Ernährung und Landwirtschaft, grant no. 2814703611.

*The $\boldsymbol{e}$-Xtra logo stands for "electronic extra" and indicates that three supplementary figures and one supplementary table are published online.

The authors declare no conflict of interest.

Accepted for publication 12 December 2018.

() 2019 The American Phytopathological Society blossom (Kunkel 1945). Today, however, even though heat therapy has been commonly applied for virus elimination in a wide range of host plants, its potential for phytoplasma eradication has been much less explored (Chalak et al. 2013). Hollings and Stone (1970) used heat therapy to treat chrysanthemum stunt in 'Mistletoe' chrysanthemums, but from 72 plants which were successfully regenerated from them via meristem-tips, only two plants stayed without symptoms. More recently, it was reported that stem cutting culture coupled with heat therapy is effective for the elimination of 'Candidatus Phytoplasma phoenicium' from Lebanese almond (Prunus dulcis) varieties (Chalak et al. 2005), as well as for elimination of Bois noir phytoplasmas from grapevine (Vitis vinifera) (Chalak et al. 2013). For woody plant material like grapevine scions, hot water treatment has also been reported as an effective heat therapy against phytoplasmas (Bianco et al. 2000; Tassart-Subirats et al. 2003). In addition, tissue culture alone without any prior heat therapy but based on apical meristems and embryogenic callus was shown to eliminate phytoplasmas from sugarcane (Parmessur et al. 2002). Furthermore, heat therapy was found to eliminate ' $\mathrm{Ca}$. Liberibacter asiaticus', a phloemlimited gram-negative bacteria, from infected citrus trees (Hoffman et al. 2013).

In this study, the efficacy of heat therapy with subsequent tissue culture to eliminate phytoplasmas from infected raspberry (Rubus idaeus) and blackberry (Rubus subgenus Rubus) plants is evaluated in order to determine the feasibility of heat therapy as a routine tool to ensure the presence of phytoplasma-free mother plants in nurseries and thus the propagation of phytoplasma free plant material.

\section{Materials and Methods}

Plant material. Phytoplasma-infected raspberry (Rubus idaeus) plants of the cultivar Tulameen and blackberry (Rubus subgenus Rubus) plants of the cultivar Loch Ness were kindly provided by Michael Petruschke (Agricultural Technology Centre [LTZ], Augustenberg, Karlsruhe, Germany). These infected plants were originally multiplied from a sampled raspberry and a sampled blackberry plant which were dug out of a commercial fruit farm in Rielingshausen in Southern Germany ( $\left.48^{\circ} 57^{\prime} 31^{\prime \prime} \mathrm{N} 9^{\circ} 20^{\prime} 08^{\prime \prime} \mathrm{E}\right)$. The plants were multiplied by splitting their root balls in order to have a sufficient number of infected plants for the heat therapy experiment.

The plants were carefully precultivated in order to help them cope with the heat treatment while still producing vigorous shoots with vital meristems. For the precultivation, a substrate mixture of brill type 
5 (Gebr. Brill Substrate GmbH \& Co. KG, Georgsdorf, Germany): sand: perlite $=1: 1.2: 0.3$ was used and plants were watered manually as required. Liquid fertilizer (Kristalon Blaumarke, YARA GmbH \& Co. KG, Dülmen, Deutschland) was applied individually according to growth rate. The woody canes were cut back in order to force numerous root shoots. With new root shoots of 5 to $10 \mathrm{~cm}$ in length, the pots were transferred to the heat cabinet, where they were inserted in full depth in moist peat to give further heat protection. The size of the plants at the beginning of the heat therapy varied in a broad range which supposedly was caused by the infection status.

Heat therapy. Heat therapy was performed in a heating cabinet built by the Institute of Agricultural Engineering of the University of Bonn in Germany (Supplementary Fig. S1). Size and dimensions of the cabinet (inner space for plants' growth: $1,500 \mathrm{~mm}$ high, $1,780 \mathrm{~mm}$ wide, $600 \mathrm{~mm}$ deep) allowed treatment of up to 15 plants in pots with a volume of 3 liters at the same time. Light was provided for $16 \mathrm{~h}$ per day by four metal-halide lamps CHD Agro 400 (DH Licht GmbH, Wülfrath, Germany), which gave a photon flux density of $300 \mu \mathrm{mol}^{*} \mathrm{~m}^{-2} * \mathrm{~s}^{-1}$ with full light spectrum.

Altogether, 25 raspberry plants and 33 blackberry plants were treated in the heating cabinet in three batches each. Heat therapy was carried out with a day-night rhythm of $39^{\circ} \mathrm{C}$ for $16 \mathrm{~h}$ and $36^{\circ} \mathrm{C}$ for $8 \mathrm{~h}$. This rhythm proved to be tolerable by most Fragaria, Malus, Prunus, and Rubus cultivars treated in more than 30 years. All batches of raspberry and blackberry plants were treated in the heating cabinet for 38 days before explants were taken for the tissue culture. During the heat treatment, the vegetative root shoots grew up to 30 to $50 \mathrm{~cm}$ in length. Raspberry plants at the beginning of the heat therapy are shown in Supplementary Fig. S2, and raspberry plants at the end of heat therapy are shown in Supplementary Fig. S3. Again, the plants were watered manually on demand and fertilized (Kristalon Blaumarke, YARA GmbH \& Co. KG, Dülmen, Deutschland) once a week. For the third batch of raspberry plants, however, explants for the tissue culture were additionally taken 16 and 8 days earlier (after 22 and 30 days) in order to investigate the suitability of shorter heat therapy periods for Rubus stunt phytoplasma elimination. Three infected raspberry plants were used as control plants and were cultivated without heat therapy and without tissue culture for the duration of the experiment.

Tissue culture, plant regeneration, and cultivation. For the tissue culture, shoot tips with a size of approximately $20 \mathrm{~mm}$ were dissected and surface-sterilized by shaking them for $20 \mathrm{~min}$ in a calcium hypochlorite solution according to Broome and Zimmerman (1984) and rinsing them with autoclaved tap water afterward. In vitro establishment of the shoot apical meristem explants with sizes of 0.4 to $0.6 \mathrm{~mm}$ for raspberry plants and 0.5 to $0.8 \mathrm{~mm}$ for blackberry plants was carried out in microtiter plates with 24 wells on a Murashige and Skoog medium (Murashige and Skoog 1962) containing vitamins and macro- and micronutrients as depicted in Supplementary Table S1. In the establishment phase, the synthetic cytokinin 6-benzylaminopurine was added to the medium at a concentration of $2 \mu \mathrm{mol} / \mathrm{liter}$. During the proliferation phase, the auxin indole-3-acetic acid was additionally added to the medium at a concentration of $3 \mu \mathrm{mol} / \mathrm{liter}$. Due to working in subsequent batches, the duration of the in vitro culture period varied from 120 to 240 days. The hardening phase took about 30 days for all the batches and was carried out in a growing room at $23^{\circ} \mathrm{C}$ for a $16 \mathrm{~h}$ light period and $20^{\circ} \mathrm{C}$ for $8 \mathrm{~h}$ of darkness. Light was provided by two metal-halide lamps SONT Agro 400 (DH
Licht GmbH, Wülfrath, Germany), which gave a photon flux density of $200 \mu \mathrm{mol}^{*} \mathrm{~m}^{-2 *} \mathrm{~s}^{-1}$. During hardening, the plants did not receive any fertilizer. After the hardening phase, regenerated plants were cultivated outdoors in an insect-proof horticultural tunnel covered with anti-insect mesh made out of saran plastic during the growing season and in an insect proof greenhouse chamber during winter. For the hardening phase, the plants were potted in 0.2-liter pots and transferred to 0.330 -liter and later on to 1.5 -liter pots for cultivation in the insect-proof tunnel. Substrate mixture, watering, and fertilization were as mentioned above for the precultivation. However, the substrate mixture was pasteurized for $4 \mathrm{~h}$ at $80^{\circ} \mathrm{C}$ by an electrical heater (Sterilo, Harter Elektrotechnik, Schenkenzell, Germany) in order to avoid soil-borne pathogens. Because the treatments of the plants had to be performed in several batches due to the limited volume of the heating cabinet, the raspberry and blackberry plants were regenerated and cultivated for different periods of time. The exact cultivation periods for all treatments and batches are shown in Table 1.

Out of the 25 infected raspberry plants that received heat therapy, 100 plants were regenerated via tissue culture. For the blackberry plants, 65 plants were regenerated from 33 phytoplasma-infected heat-treated plants.

Phytoplasma detection. All plants were tested for the presence of phytoplasma DNA before the heat therapy and again at the end of their regeneration and cultivation periods of at least 481 days for the raspberry plants and at least 231 days for the blackberry plants (Table 1). Leaf samples were stored at $-20^{\circ} \mathrm{C}$. For DNA extraction, a mix of older and younger leaf tissue with a total weight of $1 \mathrm{~g}$ per sample was homogenized in a Bioreba extraction bag $<$ Universal $>$ (Bioreba AG, Switzerland) at room temperature in a mixture of $4 \mathrm{ml}$ of CTAB buffer (3\% CTAB, 0.1 M Tris-HCl, pH 8.0, $20 \mathrm{mM}$ EDTA, $1.4 \mathrm{M} \mathrm{NaCl}$ ) and $8 \mu \mathrm{l}$ of 2-mercaptoethanol. The filtrate was incubated in a water bath at $65^{\circ} \mathrm{C}$ for $20 \mathrm{~min}$ and was extracted with chloroform:isoamyl alcohol (24:1). Nucleic acids were obtained by isopropanol precipitation. Extracted DNA was dissolved in deionized sterile water and stored at $-20^{\circ} \mathrm{C}$ until use. The presence of phytoplasma DNA was tested by using a Multiplex TaqMan qPCR assay for detection of phytoplasmas infecting Rubus species (Linck et al. 2017). Primers and probes were synthesized by Biolegio (Nijmegen, the Netherlands). The assay was run in $25-\mu$ l reactions using the KAPA PROBE FAST Master Mix (2x) Universal (Kapa Biosystems, Cape Town, South Africa) on an iQ5 real-time thermal cycler (BioRad Laboratories, Hercules, CA, USA), with an initial denaturation step of $20 \mathrm{~s}$ at $95^{\circ} \mathrm{C}$ followed by 40 cycles with $3 \mathrm{~s}$ denaturation at $95^{\circ} \mathrm{C}$ and $30 \mathrm{~s}$ annealing and elongation at $60^{\circ} \mathrm{C}$. All samples were run in triplicate including positive controls, negative controls, and no-template controls.

\section{Results}

All raspberry and blackberry plants were tested positive for the presence of phytoplasma DNA prior to the heat therapy and tissue culture. After heat therapy, tissue culture, and cultivation periods between 231 and 565 days (Table 1), all 100 regenerated raspberry plants and all 65 regenerated blackberry plants tested negative for the presence of phytoplasmas. This includes 16 regenerated raspberry plants, which received heat therapy for only 30 days instead of 38 days and 7 regenerated raspberry plants which received heat therapy for only 22 days (Fig. 1). All three raspberry control plants

Table 1. Time periods for all carried out heat therapy treatments, sampling dates for the phytoplasma detection after heat therapy (retest), and consequential periods of regeneration and cultivation after heat therapy

\begin{tabular}{llcr}
\hline Treatment & Heat therapy & Sampling date for retest & Regeneration and cultivation period (d) \\
\hline Raspberry batch 1 & 12 Sept 2014 - 23 Oct 2014 & 10 May 2016 & 565 \\
Raspberry batch 2 & 27 Oct 2014 - 4 Dec 2014 & 10 May 2016 & 523 \\
Raspberry batch 3 & 10 Dec 2014 - 15 Jan 2015 & 10 May 2016 & 481 \\
Blackberry batch 1 & 23 Mar 2015 - 29 Apr 2015 & 31 Mar 2016 & 337 \\
Blackberry batch 2 & 12 May 2015 - 19 Jun 2015 & 31 Mar 2016 & 286 \\
Blackberry batch 3 & 29 Jun 2015 - 13 Aug 2015 & 31 Mar 2016 & 231 \\
\hline
\end{tabular}


tested positive for phytoplasma DNA in the Multiplex TaqMan qPCR assay after completion of the experiment with $\mathrm{C}_{\mathrm{q}}$-values ranging from 29.26 to 32.43 .

\section{Discussion}

Because Rubus species like raspberry (Rubus idaeus) and blackberry (Rubus subgenus Rubus) plants are produced by vegetative propagation and the time between plant infection and the development of Rubus stunt symptoms can be up to 11 months (de Fluiter and van der Meer 1953), making sure phytoplasma-free Rubus mother plants are used to produce planting material is of prime importance to stop the spread of Rubus stunt. In this study, we report for the first time on the successful elimination of phytoplasmas in raspberry and blackberry plants by heat therapy with subsequent tissue culture. So far, there is only limited literature about the elimination of phytoplasmas from infected plants via heat therapy and tissue culture. Nonetheless, single heat therapy, single tissue culture, and both methods coupled have been reported to be effective in certain host plants. In this study, the efficacy of heat therapy coupled with tissue culture to eliminate phytoplasmas from raspberry and blackberry plants is reported for the first time.

Kunkel (1941) used a hot room to investigate the efficacy of heat therapy to eliminate aster yellows in Madagascar periwinkle
(Catharanthus roseus) without subsequent tissue culture. Kunkel (1941) found that periwinkle plants treated at $38^{\circ} \mathrm{C}$ and $42^{\circ} \mathrm{C}$ for 14 days, respectively, did not show any disease symptoms 10 and 12 months after the heat therapy, respectively. Periwinkle plants that were treated at lower temperatures or for shorter periods of time all developed symptoms after heat therapy; however, the longer the treatment the longer newly developed shoots stayed without symptoms. Furthermore, Kunkel (1941) was able to cure wild tobacco (Nicotiana rustica) by heat therapy at $40^{\circ} \mathrm{C}$ for 3 weeks, while 2 weeks of heat therapy were not sufficient to kill the phytoplasmas in the roots. Kunkel also reported heat therapy without tissue culture to be effective against peach yellows in peach trees (Kunkel 1936), false blossom in cranberry plants (Kunkel 1945), and potato witches'-broom phytoplasmas from periwinkle plants (Kunkel 1943).

The first report of heat therapy coupled with subsequent meristem tissue culture to eliminate phytoplasmas from plants is from Hollings and Stone (1970). They treated Mistletoe chrysanthemum plants at $35^{\circ} \mathrm{C}$ for 14 to 37 weeks before doing meristem-tip culture. Even though all plants were symptomless for an initial period of 5 weeks and only three plants showed symptoms after 9 weeks, only two plants out of 72 stayed without chrysanthemum stunt symptoms for the total duration of the study.

\section{q PCR \\ Heat Therapy \\ Tissue Regenerated Culture and Cultivated \\ q PCR}
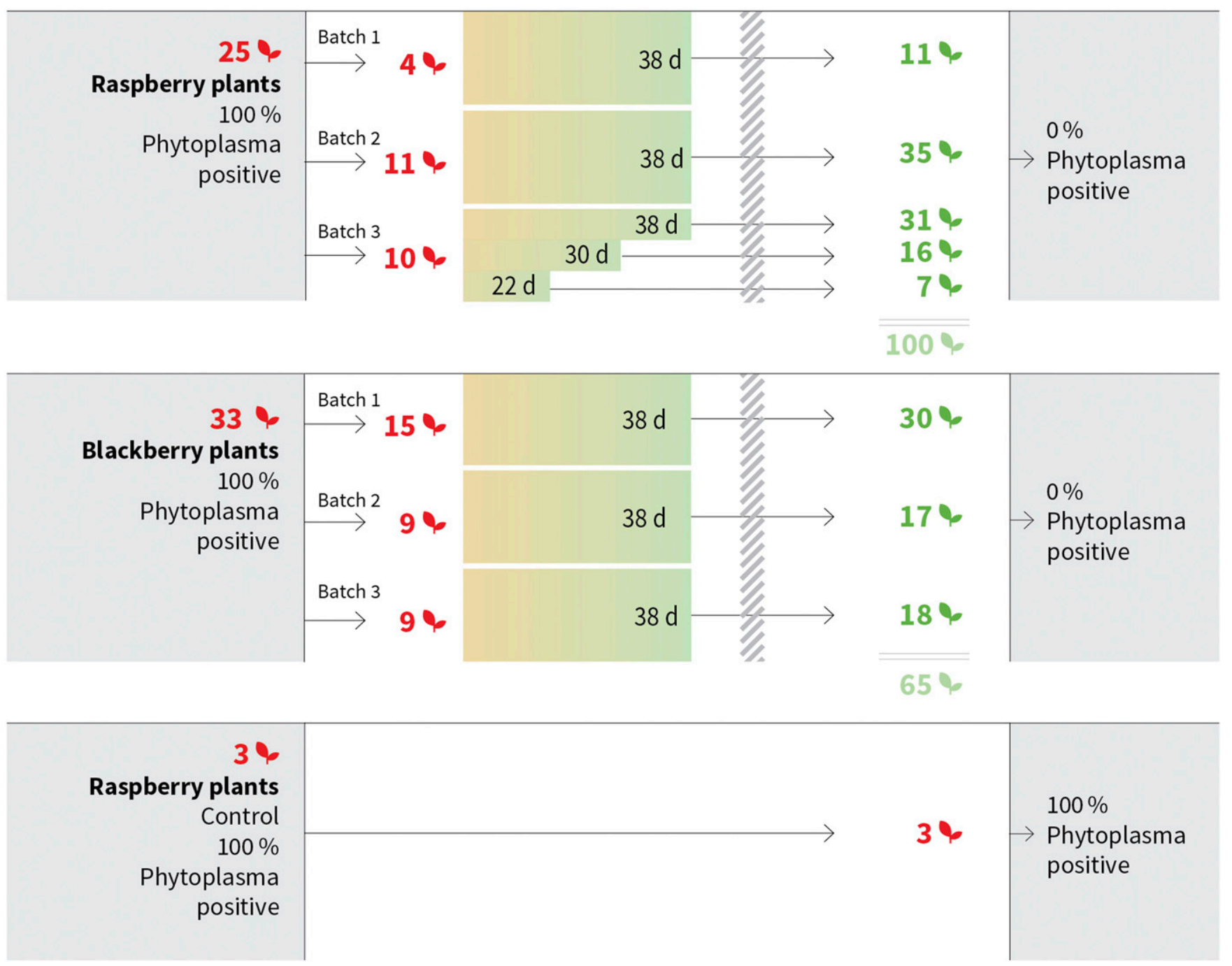

Fig. 1. Schematic diagram of the experiment including number of source plants, number of source plants per batch of heat therapy, duration of heat therapy per batch, number of regenerated and cultivated plants, and number of plants tested positive by QPCR in percent. (d) days, number of plants symbolized by leaf symbol. 
Chalak et al. (2013) performed a heat therapy at $38^{\circ} \mathrm{C}$ for 40 days during the culture process of stem cuttings and cultures of shoot tips from grapevine (Vitis vinifera). After heat therapy, newly developed shoots underwent subculturing for 30 days before they were tested by nested PCR for a first time. Afterward, explants were multiplied for two more 40-day subcultures and were subsequently tested by nested PCR again. Only $76 \%$ of shoots from the stem cutting culture with heat treatment and $76 \%$ of shoots from the shoot tip culture with heat treatment were negative in the first nested PCR after the first subculture, but all shoots were negative for phytoplasma DNA in the second nested PCR after the end of the third subculture (120 days of culture in total). In the same study, the authors also used shoot tip culture without heat therapy. While only $36 \%$ of these shoots were negative in the first nested PCR, again all shoots were negative after the third subculture. Unfortunately, Chalak et al. (2013) did not test regenerated plants for the presence of phytoplasmas after hardening and cultivation for longer periods of time. Chalak et al. (2005) did the same treatment with Lebanese almond (Prunus dulcis) varieties just at $35^{\circ} \mathrm{C}$ for 30 days, and all samples were negative for almond phytoplasma DNA in a regular PCR after 3 months of subculture; however, regular PCR is known to be often not sensitive enough to detect phytoplasma DNA in low titers (Delić 2012; Jarausch et al. 2001).

Similarly to Chalak et al. (2013), Wang and Hiruki (1996) applied heat therapy of $35^{\circ} \mathrm{C}$ to paulownia tissue cultures with typical witches'-broom symptoms for 5 weeks with subsequent meristem tissue culture. No symptoms of witches'-broom appeared in a series of subcultures after the heat therapy and plants were tested for phytoplasmas by PCR. Out of 33 analyzed plants, 31 were tested negative; however, only regular PCR was used.

While Dai et al. (1997) reported that 10 to $30 \%$ of regenerated mulberry (Morus alba) plants remained infected up to 3 years after in vitro stem culture, Parmessur et al. (2002) showed that phytoplasmas can be eliminated in sugarcane by tissue culture of apical meristems and embryogenic callus without performing heat therapy in advance. Phytoplasma elimination by tissue culture without heat therapy should be investigated in the future for Rubus species, as heat therapy is a time-consuming and therefore expensive process.

From the limited literature available on phytoplasma elimination by heat therapy and tissue culture, it can be concluded that its success relies heavily on the duration and temperature of the heat therapy and type of tissue culture. Furthermore, the species of host plant seems to play an important role. Nonetheless, there are reports of successful elimination of phytoplasmas by heat therapy without tissue culture and vice versa, providing potential treatment options for host plants which are either sensitive to heat or are difficult to handle in tissue cultures.

As plant health of Rubus spp. is currently not regulated under a growing material regulation or certification scheme in Germany, we hope that the results of this study will help to establish such regulations in order to ensure Rubus plant health.

In conclusion, heat therapy with subsequent tissue culture is a suitable method for phytoplasma elimination in raspberry and blackberry plants and is therefore an important step during the propagation process of disease-free plant material. Further investigations on reduced treatment duration of heat therapy and the effectiveness of tissue culture without heat therapy should be made in order to optimize costs for routine treatments of mother plants and nuclear stock material.

\section{Literature Cited}

Bertaccini, A. 2007. Phytoplasmas: Diversity, taxonomy, and epidemiology. Front. Biosci. 12:673-689.
Bianco, P. A., Scattini, G., Casati, P., and Fortusini, A. 2000. Thermotherapy of grapevine cuttings for flavescence dorée eradication. Pages 162-163 in: Extended Abstracts 13th Meeting of ICVG, Adelaide 2000.

Broome, O. C., and Zimmerman, R. H. 1984. Culture of shoot meristems: Fruit plants. Cell Cult. Somat. Cell Genet. Plants 1:111-122.

Chalak, L., Elbitar, A., Mourad, N., Mortada, C., and Choueiri, E. 2013. Elimination of Grapevine Bois Noir Phytoplasma by Tissue Culture Coupled or not With Heat Therapy or Hot Water Treatment. Adv. Crop Sci. Technol. $1: 1-4$.

Chalak, L., Elbitar, A., Rizk, R., Choueiri, E., Salar, P., and Bové, J. M. 2005 Attempts to eliminate Candidatus phytoplasma phoenicium from infected Lebanese almond varieties by tissue culture techniques combined or not with thermotherapy. Eur. J. Plant Pathol. 112:85-89.

Dai, Q., He, F.-T., and Liu, P.-Y. 1997. Elimination of phytoplasma by stem culture from mulberry plants (Morus alba) with dwarf disease. Plant Pathol. 46:56-61.

de Fluiter, H. J., and van der Meer, F. A. 1953. Rubus stunt, a leafhopper-borne virus disease. Tijdschr. Over Plantenziekten 59:195-197.

Delić, D. 2012. Polymerase Chain Reaction for Phytoplasmas Detection. Pages 91-118 in: Polymerase Chain Reaction. P. Hernandez-Rodriguez, ed. InTech

Hoffman, M. T., Doud, M. S., Williams, L., Zhang, M.-Q., Ding, F., Stover, E., Hall, D., Zhang, S., Jones, L., Gooch, M., Fleites, L., Dixon, W., Gabriel, D., and Duan, Y.-P. 2013. Heat treatment eliminates ' Candidatus Liberibacter asiaticus' from infected citrus trees under controlled conditions. Phytopathology 103:15-22.

Hollings, M., and Stone, O. M. 1970. Attempts to eliminate chrysanthemum stun from chrysanthemum by meristem-tip culture after heat -treatment. Ann. Appl. Biol. 65:311-315.

Jarausch, W., Jarausch-Wehrheim, B., Danet, J. L., Broquaire, J. M., Dosba, F., Saillard, C., and Garnier, M. 2001. Detection and identification of European stone fruit yellows and other phytoplasmas in wild plants in the surroundings of apricot chlorotic leaf roll-affected orchards in southern France. Eur. J. Plant Pathol. 107:209-217.

Kunkel, L. O. 1936. Heat treatments for the cure of yellows and other virus diseases of Peach. Phytopathology 26:809-830.

Kunkel, L. O. 1941. Heat cure of aster yellows in periwinkles. Am. J. Bot. 28: 761-769.

Kunkel, L. O. 1943. Potato witches'-broom transmission by dodder and cure by heat. Proc. Am. Philos. Soc. 86:470-475.

Kunkel, L. O. 1945. Studies on cranberry false blossom. Phytopathology 35: 805-821.

Lenz, F., and Lankes, C. 2006. Certification scheme for fruit trees in Germany Latv. J. Agron. 9:69-74.

Linck, H., Krüger, E., and Reineke, A. 2017. A multiplex TaqMan qPCR assay for sensitive and rapid detection of phytoplasmas infecting Rubus species. PLoS One 12:e0177808.

Mannini, F. 2007. Hot water treatment and field coverage of mother plant vineyards to prevent propagation material from phytoplasma infections. Bull. Insectol. 60:311-312.

Martin, R., MacFarlane, S., Sabanadzociv, S., Quito, D., Poudel, B., and Tzanetakis, I. 2013. Viruses and virus diseases of Rubus. Plant Dis. 97:168-182.

Mäurer, R., and Seemüller, E. 1995. Nature and genetic relatedness of the mycoplasma-like organism causing Rubus stunt in Europe. Plant Pathol. 44: 244-249.

Murashige, T., and Skoog, F. 1962. A revised medium for rapid growth and bio assays with tobacco tissue cultures. Physiol. Plant. 15:473-497.

Nienhaus, F. 1985. Viren, Mykoplasmen und Rickettsien. Ulmer, Stuttgart.

Parmessur, Y., Aljanabi, S., Saumtally, S., and Dookun-Saumtally, A. 2002. Sugarcane yellow leaf virus and sugarcane yellows phytoplasma: Elimination by tissue culture. Plant Pathol. 51:561-566.

Tassart-Subirats, V., Clair, D., Grenan, S., Boudon-Padieu, E., and Larrue, J. 2003. Hot water treatment: Curing efficiency for phytoplasma infection and effect on plant multiplication material. Pages 69-70 in: 14th Meeting of the International Council for the Study of Viruses and Virus diseases of Grapevine (ICVG).

Varveri, C., Maliogka, V. I., and Kapari-Isaia, T. 2015. Principles for supplying virus-tested material. Pages 1-32 in: Advances in Virus Research. Maramorosch, K., and Mettenleiter, T. C., eds. Vol. 91. Elsevier Inc., Oxford.

Wang, K., and Hiruki, C. 1996. PCR (polymerase chain reaction)-based selection of phytoplasma-free clones of paulownia tissue culture after heat treatment of witches'-broom. Proc. Jpn. Acad., Ser. B, Phys. Biol. Sci. 72:44-47.

Zandbergen, M. 1964. Hot water treatment for bulbs. R. Hortic. Soc. DaffodilTulip Yearb. 30:187 